\title{
Making a Case for Balkan Music Studies
}

\author{
Ivana Medić \\ Institute of Musicology, Serbian Academy of Sciences and Arts, 11000 Beograd, Serbia; \\ ivana.medic@music.sanu.ac.rs
}

Received: 5 March 2020; Accepted: 15 March 2020; Published: 25 September 2020

\begin{abstract}
In his seminal comprehensive history of music(s) in the Balkan region, Jim Samson avoided the term "Balkan music" in favor of the less-binding title Music in the Balkans (Leiden: Brill, 2013). This, however, should not hinder us from probing the term "Balkan music" and its many connotations. In this editorial article for the Special Issue Balkan Music: Past, Present, Future, I aim to dissect the umbrella term "Balkan music" and its actual and presumed meanings and implications, while overviewing many different music traditions and styles that this term encompasses. I will also make a case for the establishment of Balkan Music Studies as a discipline and attempt to outline its scope and outreach.
\end{abstract}

Keywords: the Balkans; music; oriental elements; Jim Samson; Music in the Balkans

\section{Introduction}

This Special Issue on Balkan music gathers together scholars from several disciplines (historians, historical musicologists, ethnomusicologists, ethnochoreologists, cultural theorists, and composers) from seven countries (Romania, Bulgaria, Serbia, North Macedonia, Portugal, Finland, and New Zealand) who have studied the music of the Balkans. The articles in this issue cover various regional traditions and styles, including both authentic and stylized folklore music and dance, as well as urban popular folk music, several genres of contemporary pop-folk (ethno, trepfolk, manele), music of specific ethnic groups and distinct regions within the Balkans and, last but not least, art music inspired by the vast and multifaceted Balkan heritage.

The initial idea when planning this Special Issue was to "deconstruct" and then "reconstruct" the meaning of the term "Balkan music" for Western readers. The majority of Westerners have very vague preconceptions and little actual information about Balkan music and how many diverse traditions and musical styles it encompasses. Due to this lack of comprehensive information, they tend to associate Balkan music with Roma brass bands, made famous by Emir Kusturica's feature films, or with Bulgarian female choirs, as one of the first among the many "ethnic musics" that broke into the world music markets; not to mention commercial pop-folk and various modern interpretations of traditional music that are now also absorbed into the vast global market of world music. The articles in this issue thus demonstrate the versatility and multiple uses of the term "Balkan music" and illustrate this with case studies from countries all over the Balkans with a shared cultural heritage.

This, however, should not hinder us from probing the already established (if rarely defined) term "Balkan music" and its many usages by scholars, music amateurs, music critics, bloggers, or music industry professionals. What follows is my attempt to dissect this term and its actual and presumed meanings and implications. I also wish to make a case for the establishment of the discipline of Balkan Music Studies and attempt to outline its scope and outreach. As a result of this dual goal, in this article I apply a hybrid method: whilst surveying the existing approaches in the field and commenting on the articles commissioned for this issue, I also aim to raise awareness of issues which have not merited a lot of attention before, and simultaneously point out new directions and avenues for researchers to explore in the future. 
Before the discussion of Balkan music(s), one must first define the Balkans themselves. Even an attempt to specify the countries that belong to the Balkans confronts us with different approaches, both in synchronic and diachronic perspectives. A good starting point for the present discussion is the definition of the region offered by publisher Brill, whose Balkan Studies Library, established in 2010 and edited by Zoran Milutinović and Alex Drace-Francis comprises 27 substantial monographs and edited collections. ${ }^{1}$ As per Brill's official blurb: "The region is defined here as comprising Greece, Albania, Bulgaria, Romania, Turkey, and the countries of former Yugoslavia, including their imperial Ottoman and Habsburg heritage [emphasis mine]". ${ }^{2}$ The official call for manuscripts specifies that disciplines covered by this series include history, anthropology, archaeology, political science, sociology, legal studies, economy, religion, literary studies, cultural studies, gender studies, film, theatre and media studies, art history, language and linguistics. However, as of 2020, only one book (albeit, a hefty one of 729 pages) is dedicated solely to music-Jim Samson's Music in the Balkans-while the disciplines that constitute the core of this edition include politics, economy, history, ethnology/anthropology, linguistics, and gender studies.

As to the ever elusive geopolitical position of the Balkans within Europe, many scholars have pointed out that "the Balkans" is not just a geographical term (a shorthand for the Balkan Peninsula in Southeast Europe) or a cultural region, but a complex cultural construct. Several authors have attempted to deconstruct the stereotypes that the term "Balkan" carries and show how these stereotypes were historically constructed, culturally approved, disseminated, internalized and politically charged (Bakić-Hayden and Hayden 1992, pp. 1-15; Wolff 1994, pp. 1-16; Bakić-Hayden 1995, pp. 917-22; Todorova 1997; etc.), while others have discussed the Balkans as Europe's "incomplete Other", "half-Other", or "a meeting point of the East and the West" (Iordanova 2001; Goldsvorti 2005; Laušević 2007; Jezernik 2010). As Maria Todorova has articulated in Imagining the Balkans, "the Balkans" is "a sum of stereotypes and prejudices about this region" (Todorova 1997). The volatile relationship between the Eurocentric forces and the forsaken periphery is amplified by the Ottoman legacy in the Balkans, which represents a religiously, socially, institutionally, and even racially "alien" imposition on the autochthonous Christian/European core of Balkan societies (cf. Todorova 1997, p. 162). Milica Bakić-Hayden has introduced the concept of nesting orientalism, explaining a tendency of each region to view the cultures and religions to its South and East as more conservative and primitive; hence a culture which creates the Orientalized other can also be the subject of Orientalization by another group. Within Eastern Europe, the Balkans is perceived as the most "eastern" (read: conservative and primitive), and such hierarchy continues both within the Balkans themselves (cf. Bakić-Hayden 1995, pp. 917-31) and outside of this region; as Slovenian philosopher Slavoj Žižek has commented on these fluctuating boundaries: "Where does it begin? For Serbs, it begins down there in Kosovo or Bosnia, and they defend the Christian civilization against this Europe's Other. For Croats, it begins with the Orthodox, despotic, Byzantine Serbia, against which Croatia defends the values of democratic Western civilization. For Slovenes, it begins with Croatia, and we Slovenes are the last outpost of the peaceful Mitteleuropa. For Italians and Austrians, it begins with Slovenia, where the reign of the Slavic hordes starts. For Germans, Austria itself, on account of its historic connections, is already tainted by the Balkanic corruption and inefficiency. For some arrogant Frenchmen, Germany is associated with the Balkanian Eastern savagery" (Žižek 1999).

Another related and equally ambiguous term is "Western Balkans". Since I wish to avoid debates regarding the justification and feasibility of the use of this term, I will just state that "Western Balkans" refers to the Balkans without Greece, Turkey, Romania, and Bulgaria; i.e., it only encompasses Albania and the former Yugoslav Balkan countries of Bosnia and Herzegovina, North Macedonia, Montenegro,

As of Volume 28, the series is published by Verlag Ferdinand Schöningh.

"Balkan Studies Library", Brill, https://brill.com/view/serial/BSL. 
Serbia, and Kosovo. ${ }^{3}$ Half of them are countries of disputed borders and territories, confederal status, or even names (Serbia/Kosovo, ${ }^{4}$ Bosnia and Herzegovina, ${ }^{5}$ and North Macedonia ${ }^{6}$ ) and, as of September 2020, none of them is a member of the European Union. The latter might be the defining criterion for their grouping into the imaginary "Western Balkans" (with a very notable omission of Turkey, which is also still outside of the EU, in spite of its long-standing status as a candidate). As observed by Sonja Zdravkova Djeparoska in this Special Issue, "the political neologism Western Balkans [is] a solution par excellence for the EU to distance itself from the 'most problematic' part of the Balkans awaiting its chance to join the EU family" (Zdravkova Djeparoska 2020, p. 2).

\section{Definition (of Sorts)}

So, what is "Balkan music"? The answers to this question are by no means unipolar and depend on our viewpoints, experiences, and aspirations. In his seminal history of music(s) in the Balkan peninsula, published in 2013, British musicologist Jim Samson avoided the term "Balkan music" in favor of the less-binding title Music in the Balkans. His decision was governed by a realization that one cannot apply a singular umbrella term such as "Balkan music" when faced with countless mutually different practices and traditions from the realms of art, popular, sacred, urban folk, and rural folk music. Thus, the syntagm "Balkan music" may apply (but not be limited) to:

- Any kind of music created in the Balkans (with the notion of "the Balkans" understood both as a physical/geographical and symbolic/cultural space);

- Music created anywhere in the world by musicians who originate from the Balkans;

- Music created anywhere in the world using the recognizable features of the music of the Balkan countries as its model, influence, or source of inspiration;

- A cultural construct, which implies that there exists a common Balkan cultural space;

- A marketing label-usually as a subgenre of world music.

There are also many genres of "Balkan music", some of them more obvious than the others:

- Art music created in the Balkans, with or without folklore influence. This category could absorb everything-from the nineteenth century salon music and patriotic choral songs, to the present day post-avantgarde;

- $\quad$ Religious/sacred music from the Balkans, encompassing all major religions that have been present in this region throughout the centuries-mainly Orthodox Christianity and Islam, as well as Judaism and Catholicism, not to mention paganism and other indigenous practices;

- Folk music from the Balkans-this term has a very wide usage and it is the most frequent association when speaking about the Balkans, encompassing such diverse practices as rural folk music, urban folk music, various modern arrangements of rural folk music, new/authored songs utilizing folk music intonations, the so-called newly-composed folk music from the second half of the twentieth century, contemporary folk-pop hybrids, etc.;

3 This designation is without prejudice to positions on status and is in line with UNSCR 1244 and the ICJ opinion on the Kosovo declaration of independence.

4 Kosovo is a partially-recognized state and disputed territory in Southeast Europe. The Assembly of Kosovo unilaterally declared independence from Serbia on 17 February 2008. Serbia continues to deny any statehood to Kosovo. As of September 2020, status-neutral talks between Serbia and Kosovo-Albanian authorities are held in Brussels, mediated by the EU.

5 In accordance with the Dayton Agreement signed in 1995 after the Bosnian War, the central government's power is limited, as the country is largely decentralized and comprises two autonomous entities: the Federation of Bosnia and Herzegovina (consisting of 10 cantons) and Republika Srpska (with a third, much smaller unit, the Brčko District, governed under local government).

6 After its declaration of independence in 1991, the country became a member of the United Nations in April 1993, but as a result of a dispute with Greece over the name "Macedonia", it was admitted under the provisional description "the former Yugoslav Republic of Macedonia" (FYROM). In June 2018, Macedonia and Greece resolved the dispute with an agreement that the country should rename itself "Republic of North Macedonia". This renaming came into effect in February 2019. 
- The so-called ethno music (an eclectic genre with folk and pop origins), popular in many Balkan countries since the 1990s;

- Music of the Roma people as a specific (meta)genre of folk music throughout the Balkans;

- Pop and rock music from the Balkans utilizing folk elements of various provenances, again in a variety of subgenres, from the Yugoslav pastirski rok [shepherds' rock] of the 1970s to the present day trepfolk—a bastard child of turbo-folk and rap/hip-hop;

- etc.

Jim Samson's landmark book Music in the Balkans documents how a highly esteemed British scholar, a self-confessed "outsider" in the Balkans, or South East Europe (which is his preferred and less prejudice-laden term) has assessed this region and signposted various problem areas. As to his preference of the term "South East Europe", he sees is as an accommodation to the European project, whereas "The Balkans" is equated with Ottoman presence and legacy in Europe and "signals the darker past of this region. Outsiders have gone so far as to generate a pejorative verb from the label, while insiders have cultivated an ethos of denial; the Balkans is always further south, further east than our present location" (Samson 2013, p. 2). Samson's explanation is in accordance with the concept of nesting orientalism; furthermore, it highlights the problem that, while chasing the ever-elusive goal of joining the family of European nations both politically and culturally, the Balkan societies (especially those with a Christian /Orthodox/ majority) are often made to feel ashamed of their Ottoman past, which has alienated them from (Christian/Catholic or Protestant/, white, occidental) Europe, regardless of how popular some elements of that oriental legacy still are among the Balkan peoples. On the other hand, there are instances where (Western) Europe actually prefers to continue to perceive the Balkans as its oriental "other", which makes it difficult for the Balkan nations to shed the stigma.

In his attempt to investigate multiple musical traditions in the Balkans and to elucidate how music has contributed to the definition of national, regional, and social identities in the region, Samson has freely crossed borders between musicology and ethnomusicology. The official blurb suggests that the author's ultimate goal was "to elucidate the relationship between politics and musical practice in a region whose art music has been all but written out of the European story and whose traditional music has been subject to appropriation by one ideology after another". ${ }^{7}$ Using a combination of academic writing with a highly engaging personal approach, Samson achieves many related goals, including an interdisciplinary synthesis of a vast range of literatures, histories, and musical styles (including art music, church music, popular music, and traditional music), whilst avoiding a long-ingrained East-West polarization in favor of a more inclusive outlook. While presenting persuasive arguments for the inclusion of Balkan art music into European canons, Samson courageously attempts to address sensitive issues without taking sides, resulting in his ultimate call for a denationalization of music history.

Samson divides his book into five major parts. "Balkan Geographies", "Historical Layers", "Music in Transition", "Eastern Europe", and "Global Balkans". Each chapter opens a new problem area; some of them focus on historical perspectives, others on territories, or these two overlap into a wide diachronic perspective, with politics always involved. Samson singles out only a few composers (Manolis Kalomiris, Josip Slavenski, George Enescu, and Mikis Theodorakis), while all other composers are discussed in the context of wider problem areas. The first part of the book engages with the (micro)geographies in the Balkans and the musical cultures of various ethnicities that have inhabited the region over the course of many centuries. The second part positions the Balkans between Byzantine and Ottoman influences and engages with the first attempts at modernizing musical life in the Balkans, which coincides with the ascent of the ideology of Yugoslavism. The central part of this monumental book deals with the interwar period and the ascent of modernism in the Balkan countries with a focus on the major figures of Kalomiris (Greece), Slavenski (Yugoslavia), and Enescu (Romania), while the

7 “Music in the Balkans", https://brill.com/view/title/23889?rskey=ytlm1L\&result=1. 
fourth part is dedicated to the post-World War II communist period. The final part of the book assesses the situation after the downfall of communism and the mass migrations that occurred.

Samson points out that South East Europe "resides in the margins of music histories, a footnote at best. [ ... ] Although it is part of Europe's cultural heritage, it has been all but written out of the European story. There are obvious reasons for this, to do with the political, social and cultural consequences of Ottoman rule. The familiar scenery of European modernity appeared late in South East Europe" (Samson 2013, p. 1). On the other hand, he observes a continuous interest in traditional music of the Balkans which "has long been a hunting ground for scholars from without, and especially from the North American college circle. This asymmetry is striking, and it exposes the other side of the modernity coin. Pre-modern rural music-making survived longer in the Balkans than in many other parts of Europe. Its distinctiveness, closely tied to place, has made it an easy prey for appropriation by local nationalisms, by state socialism and by exoticist agendas in the West" (Samson 2013, p. 1). Samson also notes that the "competitive cultural nationalisms of the nineteenth century may have drawn some territories from the peripheries of Europe closer to its cultural centre, but they pushed others, and especially in the Balkans, yet further away" (Samson 2013, p. 36).

One of Samson's thought-provoking hypotheses, regarding the presence of asymmetrical rhythms in the Balkans, certainly merits further investigation and verification: "Although it may be tempting to explain [ ... ] asymmetrical rhythms in terms of Ottoman legacy, it is probably more realistic to see them-as Wouter Swets has done-as indigenous to the traditional music of the entire Balkan-Anatolian region, even if it is the $u s u l$ (rhythmic cycle) of Ottoman-Turkish classical music that has provided the theoretical rationale" (Samson 2013, p. 78). Other problems identified by Samson that deserve extensive separate international and interdisciplinary research projects include:

- Russophilia among the fellow members of the Orthodox mullet (especially Serbs and Bulgarians) (pp. 63-4);

- the genre of "Ottoman cafe music", centered on the institution known as the kafe aman (music cafe) and performed all over the eastern Balkans and Anatolia in the late nineteenth and early twentieth century (p. 71);

- the importance of Roma musicians as agents of transculturation and their ability to adopt and then to personalize the idioms and genres associated with the majority nationality in a region (p. 88-9);

- the notion of Thracian regional identity in some parts of Bulgaria and Turkey (p. 92);

- a family of styles of oriental urban song in all Balkan countries (p. 102);

- the ancient genre of epic song accompanied by a gusle in which the famous deeds of heroes are recounted (p. 104);

- etc.

Another recently published book of immense importance for the present discussion (if only tangentially related to our topic) is a collective monograph, Studies on a Global History of Music. A Balzan Musicology Project, edited by Reinhard Strohm. The editor's goal was to devise "conceptual frameworks for a history of music that abandons Eurocentrism and pays due attention to global relationships" (Strohm 2018, p. xiii). While Strohm and his contributors mostly deal with neglected Asian, African, and aboriginal music traditions and omit the forgotten parts of Europe, it is fairly obvious that the Balkans should be one of those "new" areas included in a global, anti-(West)Eurocentric, anti-hegemonic history of music. In the essay that opens the book, Studies on a Global History of Music, "Notes and queries on 'global music history'", British ethnomusicologist Martin Stokes reassesses the usability of disciplines such as comparative musicology, ethnomusicology, post-colonial studies, globalization theory, and sound studies for the purpose of writing the desired fair-and-just global music history. His analysis is very relevant for the nascent field of Balkan Music Studies. While reviewing the merits of comparative musicology, in spite of its entanglement with the colonial and evolutionist thinking of the early twentieth century, Stokes rightfully observes: "If some appear to us to 'have' history and others 'do not', the first question for the ethnographer must, then, be how one explains the 
distributional imbalance, the political economy. What role have we played, to start off with, in either entirely removing people from history, or, as Dipesh Chakrabarty put it, consigning them to history's 'waiting room'? (... ) Somebody has been silenced, by somebody, for a reason. 'People without history' have been made so by others who gain from having it" (Stokes 2018, p. 7). As to ethnomusicology, Stokes agrees with Kofi Agawy who is doubtful of ethnomusicology's tendency to focus "insistently on the 'traditional' at the expense of the emergent, the modern, the popular, the translocal" (Agawu 1992; cited in Stokes 2018, p. 8). On the other hand, Stokes insists that post-colonial theory is inadequate to deal with the hitherto neglected territories because it "insistently speaks a first-world theoretical language. ( ... ) It has claimed to speak globally, but tends to restrict itself to British and French colonial and post-colonial experience" (Stokes 2018, p. 9). The globalization discourse is no less suspicious, because the questions of agency in a global world are largely overlooked. Stokes rightfully asks who labels certain music as "'global' or 'world music', when and for what purposes? Who has the power to define and exploit such situations, who to resist? (... ) What hidden and inaudible infrastructures channel this flow, and who presides over them?" (Stokes 2018, p. 12). Thus, he concludes that "Western music history has rarely regarded its others as antagonists or persecutors. The worst that can probably be said of it is that it has habitually regarded them as pliant sources of raw material" (Stokes 2018, p. 13). This observation matches Samson's previously cited remark that the Balkans have long served as a hunting ground for scholars interested in pre-modern rural music-making and exoticism, instead of being treated as equal to the rest of Europe.

\section{Topics and Approaches}

This Special Issue on Balkan music opens several new areas of investigation, or shakes up the existing ones. British/Portuguese composer and scholar Ivan Moody has long studied the shared features of the South European/Mediterranean cultures, in particular their common responses to the challenges of modernization, as well as the remnants of the Byzantine heritage in these territories. In the article "The Idea of Byzantium in the Construction of the Musical Cultures of the Balkans" (Moody 2020) he identifies the post-Byzantine idea of the Byzantine as one of the most original aspects of Balkan art. Moody observes that Byzantinism is intimately connected with Balkanism, and the quest for the rehabilitation of the former has much to do with the need for self-affirmation of the latter. He examines ways in which the idea of Byzantium persisted in Balkan artistic cultures (and especially in music) and illustrates the strength of Byzantinism as a pan-Balkan characteristic. Drawing on Angelov (2003) and Cameron (2006, 2014), Moody also shows that Western tendency to overlook Balkan and/or Eastern European cultures is related to a wider dismissal of "the Byzantine" in the West, because it "lies outside the standard western narrative of the formation of Europe ( . . ) consigned to the twin spheres of exoticism and the east" (Cameron 2014, cited in Moody 2020, p. 1).

Moving on to individual case studies in several Balkan countries, in the article "De-Balkanizing the Balkan: Case Studies in Romanian Ethno-Rock and Metal, and Manele" Claudiu Oancea discusses the specificity of Romania in the cultural context of other Balkan countries, considering the Romanian people's general reluctance to associate themselves with the Balkans (perceived as something barbaric, wild, and lawless) and opting instead to view themselves as a modern European nation, "a lost Eastern remnant of Western civilization" (Boia 2001, cited in Oancea 2020, forthcoming). Oancea's article is the first to analyze different appropriations of Balkan folk music influences in Romanian ethno-rock and metal on the one hand, and manele (ethno-pop) on the other. Although the genre of manele in Romania is regarded with disdain due to its Balkan and Eastern (read: Ottoman, Muslim, Romani, Asian) roots and characteristics, the author points out that musicians profit from their association with the Balkan 'brand' and deliberately emphasize oriental elements in their music. ${ }^{8}$ On the other

8 Marija Dumnić [Vilotijević] uses the term autobalkanism to denote this phenomenon of self-identifying with the Balkan 'brand' and related stereotypes (Cf. Dumnić 2012). 
hand, most Romanian rock musicians from the 1970s onwards avoided the adjective "Balkan" at least nominally and reiterated some old prejudices, while actually absorbing some elements of Balkan folk traditions, such as uneven ( $a k s a k)$ rhythms. Oancea argues that reasons for this revolve around "Romania's process of nation building, which combined an avid obsession for Western models with an attempt to find its own cultural originality" (Oancea 2020, forthcoming).

Moving south, in the article "Traditions in the Discussions about the obrabotvane of Folklore in the Avtorski Pesni v Naroden Duh from Bulgaria" ethnomusicologist Lozanka Peycheva reviews the status of newly-composed ("authored") folk songs and their evolution into "folk" songs (Peycheva 2020). She opens up the problem area of the existence of intonation funds and musical folklore matrices in Balkan countries and their presumed interconnectedness, which merits profound investigations in the future. Peycheva also tackles the controversies surrounding the notion of the obrabotvane (transformation, polishing, processing, cultivation, treatment) of folklore and argues that, as a meta-genre, avtorski pesni $v$ naroden duh are "undoubtedly a modern, multi-faceted and many-sided phenomenon, originating from modern institutions such as the mass media and the music market (...) The development of avtorski pesni $v$ naroden duh is a story of the replacement of tradition by modernity" (Peycheva 2020, p. 2). This highlights a common problem in all Balkan societies, related to the processes of (belated) modernization, and the dialectics of constant attempts to 'upgrade' these societies and 'catch up with the West', while preserving something 'authetically our own' (including various responses to the folklore heritage).

Two authors deal with the music scenes in Serbia, offering mutually different, but complementary perspectives. The article "Contested Imaginings of the Serbian Self and the Romani Other in Serbia's Guča Trumpet Festival" by Jelena Gligorijević is particularly timely, given the recent global unrest over racial unequity. Gligorijević analyzes the hierarchy of Others in the Balkans and brings to the surface the implicit racism, as well as rivalry between "white" and Roma brass bands at the famous Guča Trumpet Festival in Serbia. Her study illustrates the ambiguous ways in which the racialization of the Serbian Self and the Romani Other unfolds alongside the country's and region's persistent denial of racial issues, relying on the recent debates about race and racism in South/Eastern Europe within the broader context of postsocialist transition, EU integration, and globalization. She presents ample evidence to challenge the commonly held view among South/Eastern Europeans that their region somehow stands outside of race, because its history is exempted from discourses of race, coloniality, and imperialism. Moreover, in spite of the recent emergence of the new paradigm of Balkan transnationalism, Gligorijević argues that Balkanism, as "a Southeast European variant of postcolonial theory" remains "analytically most helpful in pointing to the uncontested hegemony of Western/European white privilege and supremacy" (Gligorijević 2020, p. 1), especially in the context of Serbia's indeterminate position between West and East. She provides additional insight into the notions of tribal stigma and spoiled identity (Gligorijević 2020, p. 2), which are also related to the previously mentioned concept of nesting orientalism.

In the article "The Balkans of the Balkans: The Meaning of Autobalkanism in Regional Popular Music", Marija Dumnić Vilotijević discusses contemporary popular folk music produced in Western Balkans for domestic audiences and diaspora communities, including the first scholarly discussion of the newest genre of trepfolk, which combines imitations of global mainstream popular music (e.g., dancehall) with local practices of popular folk music, including lyrics that reiterate (auto)stereotypes about the Balkans. Dumnić Vilotijević draws on her earlier discussions of autobalkanism (Dumnić 2012, p. 348) to overview Balkan sterotypes "invented as external associations (outside of the Balkans) and (...) consequently internalized in the Balkans" (Dumnić Vilotijević 2020, p. 1) and argues that this peculiar cultural appropriation also serves as a significant marker for Balkan diaspora communities.

The remaining two articles are devoted to musical practices in North Macedonia. In her article "Macedonian Cultural Plurality at the Crossroads of the Balkans: Drama, Music and Dance" Sonja Zdravkova Djeparoska regards the Balkans as a cultural, political, religious, linguistic, and ideological concept, but also as a mentality, emotion, energy. The author addresses the "problematic" (from the 
European standpoint) Turkish-Ottoman-Muslim "connection", resulting in the stereotypes of the Balkans as a "primitive", "backward", "tribal", "uncivilised", "conflicting", "unfortunate" Other of Europe. These stereotypes are especially stigmatizing for the recently renamed state of North Macedonia, a country completely "confined" to the Balkans, unlike some of its neighbors who can claim alternative identities in order to escape these prejudices (e.g., Serbia-Central European; Greece, Montenegro and Albania-Mediterranean). Zdravkova Djeparoska correctly observes that, after the dissolution of the Socialist Federal Republic of Yugoslavia, "The Balkans" have increasingly been regarded as "a substitute for the Yugoslav cultural concept" (Zdravkova Djeparoska 2020, p. 3), and asserts that "the cultural forms of Macedonian culture are only part of the wider pluralistic representation of the Balkans" (Zdravkova Djeparoska 2020, p. 1). At the same time, within the concept of the Balkans, "there is always a need to emphasize and underline specifics (mostly national). The constructed whole for the Balkan population is always visible as a mosaic, collage, patchwork of independent parts that are functioning together" (Zdravkova Djeparoska 2020, p. 3).

In the article "Not Different Enough: Avoiding Representation as 'Balkan' and the Constrained Appeal of Macedonian Ethno Music" Dave Wilson presents a case study, based on his long-standing investigation of (and participation in) Macedonian music practices, which draws similar conclusions to Oancea's analysis of Romanian bands. Wilson analyzes the output of North Macedonian ethno musicians who are reluctant to emphasize Balkan elements in their music, resulting in their diminished marketability in the (Western) world music markets. The reason why North Macedonian ethno musicians avoid the Balkan tag and focus on the synthesis of Byzantine Orthodox and folk-rural traditions is because they aim to establish a distinct (North) Macedonian identity and distance themselves from oriental (Turkish, Arabic, Romani, etc.) elements. Yet, since an average Western listener tends to equate "Balkan" with "Oriental", to their ears Macedonian ethno music paradoxically sounds insufficiently exotic and authentic: "their avoidance of the term "Balkan" and associated stereotypes constrains their popularity to Macedonian audiences and prevents them from participating widely in world music festival networks and related markets" (Wilson 2020, p. 1). Wilson cites Aleysia Whitmore's apt conclusion that music industry personnel "discipline and manage musics by reproducing stereotypes and placing limits on how audiences perceive musicians [... ] They create a straw man against which Westerners define themselves and that justifies treating the 'Other' differently" (Whitmore 2016, p. 333, cited in Wilson 2020, p. 16). A similar expectation to appeal to the exoticizing gaze of world music audiences is present among Serbian ethno musicians as well. In my earlier study of the band Arhai's transition from being a part of the Serbian early twenty-first century ethno music scene to becoming a part of the global world music scene (Medić 2014), I defined Serbian etno muzika as "a comprehensive cultural and marketing construct that encompasses a variety of musical practices: from reconstructions and performances of the oldest layers of rural music, through 'modernised' arrangements of traditional songs for vocal and instrumental ensembles, to a variety of genres of popular music (pop, jazz, techno) loosely based on folk music models (with or without actual citations)" (Medić 2014, p. 110). This genre emerged in the 1990s and gained particular prominence after Slobodan Milošević was overthrown in 2000 , because it complied with the ideology of preservation and promotion of Serbian national identity and cultural heritage and avoided "oriental" influences (e.g., melismatic singing, the instruments such as the zurle, the hijaz tetrachord, and such) —in stark contrast to the two dominant genres of popular folk music of the 1980s and 1990s, namely novokomponovana narodna muzika (the newly-composed folk music) and turbo folk; the latter in particular was regarded by several cultural theorists as the symbolic soundtrack of Milošević's despotic rule (Dragićević-Šešić 1994; Gordy 1999; Kronja 2000). However, ethnomusicologist Mladen Marković points out that the supposedly authentic tradition was often distorted when packaged as ethno and that the entire ethno music catalogue actually contains little Serbian traditional music, because "there is Walachian, Bulgarian, Macedonian, Greek, even Hungarian music" (Marković 2002, p. 50); moreover, he observes numerous incongruities in the self-proclaimed "modernization", "blending", and "reshaping" of tradition in the works by ethno artists such as the Teofilović brothers, Sanja Ilić, Bilja Krstić, and Slobodan Trkulja (Marković 2012, pp. 341-43). 
However, unlike their Macedonian counterparts described by Wilson and Zdravkova Djeparoska, many Serbian ethno musicians are happy use the adjective "Balkan" as a marketing tool, both in domestic and foreign markets. A number of Serbian ethno bands feature "Balkan" in their names (Sanja Ilić's Balkanika, Slobodan Trkulja's Balkanopolis, and Jovan Maljoković's Balkan Salsa Band); and even more compositions and albums of ethno music (by artists such as Ognjen i prijatelji, Bora Dugi', Darko Macura, Slobodan Trkulja, Sanja Ilić, Arhai, and many others) relate to the Balkans through their name, as observed by ethnologist Ivan Čolović and myself (cf. Čolović 2004, p. 59; Medić 2014, p. 112)

In 1996 Bojan Đorđević founded a festival of alternative music Ring Ring and a CD edition for the label B92, which mostly issued licensed records of world music stars previously released by European record companies. However, this edition went on to include some domestic performers-notably Roma singers and brass bands. As members of the Roma ethnic minority and performing music that sounded sufficiently exotic to Western ears, they were easily accepted into the global world music canon. However, these Roma singers and brass bands became acceptable to members of Serbian educated elite only after they were successfully "exported" to the West as world music stars! Soon afterwards, other folk musicians from Serbia also began to feature in world music stores. The Western retailers, however, never attempted to distinguish between the Serbian stars that belonged to distinctive genres of turbo folk, folk rock, new folk, or ethno, because they all sounded sufficiently "exotic" to Western listeners, who were largely unaware of the political, cultural, and class boundaries that separated these genres. The musicians themselves are well aware of this difference; for example, Bilja Krstić, the leader of the band Bistrik, stated: "When performing in Serbia, we are considered ethno, but when we perform outside the country, at an international festival, we are featured as world musicians" (cited in Marković 2012, p. 334). Thus, when attempting to sell their music worldwide, the exponents of Serbian ethno music allow to be marketed as world music stars; however, in their own countries, the very same music serves as a symbol of something "national", "ethnic", and "authentically our own". In both cases, however, the Balkan moniker is used as a unique selling proposition: in the domestic setting, it reinforces the musicians' and the listeners' connection with their roots, their land, their history, and traditions; while in an international setting, it emphasizes their "exoticness" and "Orientalness" and makes them more attractive to world music enthusiasts (cf. Medić 2014). Thus, I concur with Philip V. Bohlman's observation that "the space between the West and its others persists not because of the shifting geographies of global encounter but rather because of an endemic imbalance of power" (Bohlman 2002, p. 39) and that world music can be perceived as "homogenized global pop, cultural imperialism made sonorous, as well as a metaphor for the hegemony of the West" (Bohlman 2002, p. 147). In the process of commodification and dissemination of world music, the products from different parts of the world are ripped from their original contexts and transferred into new, often incompatible settings. During this transfer, the function and position that this music occupied in its original context is rendered unimportant, because it has to fit into Western systems of values and hierarchies; and this, in turn, impacts how this "exported" music is then re-assessed in its original context (cf. Medić 2014, p. 110).

On the other hand, a similar self-identification with their Balkan roots is also found among the composers of art music who left the Balkan countries in pursuit of international success. In my book dedicated to Serbian art music diaspora (Medić 2020), I discussed the fact that, while still in Serbia, most art music composers lived and worked in urban centers and employed modernist, "cosmopolitan" styles, with very limited contact with Serbian and Balkan folk music. However, after moving abroad, many of them began to reach for some elements of traditional music, including ancient spiritual chants and elements of the oldest folk rites and rituals (some of them even predating the Christianization of the Balkans). In most cases, the reason for this turn to "sources" was not nostalgia, but the desire to offer something original, indigenous and unexplored to their new, international audiences (cf. Medić 2020, pp. 26-27). As remarked by composer Aleksandra Vrebalov: "The way people in the USA reacted to this was a revelation, because the material that was so familiar and 'domestic' to me 
was like a treasure mine that opened before them, both in terms of harmony, melodies and rhythms" (cited in: Gojkov 2019). Hence, just like their popular music counterparts, art music composers working in competitive Western markets use their "Balkanness" as a major selling proposition.

\section{Balkan Music Studies-Mapping the Field}

At the moment of writing this editorial article, there are numerous universities and institutes that foster research in the field of Balkan Studies and/or offer undergraduate (BA), graduate (MA), and postgraduate (MPhil, PhD) degrees. Many of these study programs are interdisciplinary and welcome applicants from the fields of history, geography, languages and literatures, politics, economy, ethnology and anthropology, cultural, and gender studies, etc. The graduates of these institutions can find employment as teachers, lecturers, diplomats, journalists, researchers, politicians, etc. Yet, among the institutions that I have located in eighteen countries on three continents, only one (!) includes a module on Balkan Music - the Balkan Research Institute at the Trakya University, Edirne, Republic of Turkey (Table 1). It seems that it is still accepted as a given that music should be taught elsewhere-at specialized music schools, academies, conservatories, universities; and the same observation also applies to the related field of dance.

Table 1. Balkan Studies at universities and institutes worldwide.

\begin{tabular}{|c|c|c|c|}
\hline Country & City & Institution & Discipline \\
\hline Albania & Tirana & $\begin{array}{l}\text { Albanian Institute for } \\
\text { International Studies }\end{array}$ & Politics, international relations \\
\hline Austria & Graz & $\begin{array}{c}\text { Centre for Southeast European Studies, } \\
\text { University of Graz }\end{array}$ & $\begin{array}{l}\text { MA and PhD in Southeastern Europe } \\
\text { studies, law and politics }\end{array}$ \\
\hline $\begin{array}{l}\text { Bosnia and } \\
\text { Herzegovina }\end{array}$ & Sarajevo & $\begin{array}{c}\text { Center for Balcanological Investigations, } \\
\text { Academy of Sciences and Arts of Bosnia } \\
\text { and Herzegovina }\end{array}$ & $\begin{array}{l}\text { Archaeology, ethnology, history, } \\
\text { linguistics, anthropology }\end{array}$ \\
\hline Bulgaria & Sofia & $\begin{array}{l}\text { The Institute of Balkan Studies, } \\
\text { Bulgarian Academy of Sciences, with } \\
\text { Centre for Thracology "Prof. } \\
\text { Alexander Fol" }\end{array}$ & $\begin{array}{c}\text { PhD in history and archaeology, } \\
\text { philology, sociology, anthropology, and } \\
\text { cultural Studies }\end{array}$ \\
\hline Czech Republic & Brno & $\begin{array}{c}\text { South Slavonic and Balkan Studies, } \\
\text { Masaryk University }\end{array}$ & $\begin{array}{l}\text { BA in languages (Bulgarian, Croatian, } \\
\text { Slovenian, Serbian, North Macedonian); } \\
\text { literature, ethnology, history, political } \\
\text { science, journalism, geography }\end{array}$ \\
\hline Czech Republic & Prague & $\begin{array}{c}\text { Department of South Slavonic and } \\
\text { Balkan Studies, Faculty of Arts, Charles } \\
\text { University in Prague }\end{array}$ & $\begin{array}{c}\text { Languages (Albanian, Bulgarian, } \\
\text { Croatian, Romanian, Serbian and } \\
\text { Slovenian), literature, history }\end{array}$ \\
\hline Denmark & Aarhus & $\begin{array}{l}\text { School of Culture and Society-Russian } \\
\text { and Balkan Studies, Aarhus University }\end{array}$ & History, society, culture, languages \\
\hline Denmark & Copenhagen & $\begin{array}{c}\text { Department of Cross-Cultural and } \\
\text { Regional Studies, Eastern European } \\
\text { Studies (formerly Balkan, Polish and } \\
\text { Russian Studies) }\end{array}$ & $\begin{array}{c}\text { Identity politics, memory politics and } \\
\text { uses of history, cultural } \\
\text { history, languages }\end{array}$ \\
\hline Finland & Helsinki & $\begin{array}{c}\text { The Aleksanteri Institute East Central } \\
\text { European, Balkan and Baltic } \\
\text { Studies (ECEBB) }\end{array}$ & $\begin{array}{l}\text { Politics, history, area and } \\
\text { cultural studies }\end{array}$ \\
\hline France & Paris & $\begin{array}{c}\text { Center for Turkish, Ottoman, Balkan } \\
\text { and Central Asian Studies (CETOBAC), } \\
\text { The School for Advanced Studies in the } \\
\text { Social Sciences (EHESS) }\end{array}$ & $\begin{array}{l}\text { History, sociology, anthropology, } \\
\text { linguistics, geography, politics }\end{array}$ \\
\hline
\end{tabular}


Table 1. Cont

\begin{tabular}{|c|c|c|c|}
\hline Country & City & Institution & Discipline \\
\hline Greece & Athens & $\begin{array}{c}\text { Arcadia Center for Hellenic, } \\
\text { Mediterranean and Balkan Studies and } \\
\text { Research, Vocational Schools Pagrati }\end{array}$ & $\begin{array}{l}\text { Anthropology, politics, archaeology, } \\
\text { languages, philosophy, ethnology }\end{array}$ \\
\hline Greece & Athens & $\begin{array}{c}\text { National and Kapodistrian University } \\
\text { of Athens-MA in Southeast European } \\
\text { Studies }\end{array}$ & Politics, history, economics \\
\hline Greece & Athens & $\begin{array}{l}\text { The Research Institute for European and } \\
\text { American Studies (RIEAS)_-Balkan and } \\
\text { Mediterranean Studies }\end{array}$ & Politics and related disciplines \\
\hline Greece & Thessaloniki & $\begin{array}{l}\text { University of Macedonia, Department } \\
\text { of Balkan, Slavic and Oriental Studies }\end{array}$ & $\begin{array}{l}\text { BA in economy and law; policies and } \\
\text { social sciences, including culture; } \\
\text { Balkan, Slavic, and Eastern languages }\end{array}$ \\
\hline Greece & Thessaloniki & Institute for Balkan Studies (IMXA) & $\begin{array}{c}\text { History, archaeology, culture, } \\
\text { international relations, economics; } \\
\text { Balkan languages, Russian, } \\
\text { Polish, Greek }\end{array}$ \\
\hline North Macedonia & Skopje & $\begin{array}{c}\text { International Balkan University Faculty } \\
\text { of Humanities and Social Sciences }\end{array}$ & $\begin{array}{l}\text { Psychology, political sciences, and } \\
\text { religious studies }\end{array}$ \\
\hline North Macedonia & Skopje & $\begin{array}{c}\text { The Institute for Social Sciences and } \\
\text { Humanities "Euro-Balkan" }\end{array}$ & $\begin{array}{l}\text { Gender studies, cultural studies, social } \\
\text { studies, Byzantine studies }\end{array}$ \\
\hline Poland & Poznan & $\begin{array}{c}\text { Central European and Balkan Studies, } \\
\text { Faculty of Polish and Classical } \\
\text { Philology, Adam Mickiewicz } \\
\text { University Poznan }\end{array}$ & Languages, literature, culture \\
\hline Serbia & Belgrade & $\begin{array}{l}\text { Institute for Balkan Studies, Serbian } \\
\text { Academy of Sciences and Arts }\end{array}$ & $\begin{array}{l}\text { Archaeology, history, art, anthropology, } \\
\text { literature, ethnography, culture, law }\end{array}$ \\
\hline Serbia & Belgrade & Western Balkans Institute (WEBIN) & Socioeconomic policies and practice \\
\hline Slovenia & Ljubljana & $\begin{array}{l}\text { International Institute for Middle East } \\
\text { and Balkan Studies (IFIMES) }\end{array}$ & $\begin{array}{l}\text { Politics, economy, } \\
\text { international relations }\end{array}$ \\
\hline South Korea & Hankuk & $\begin{array}{l}\text { East European and Balkan Institute, } \\
\text { Hankuk University of Foreign Studies }\end{array}$ & $\begin{array}{l}\text { Politics, economy, social issues, } \\
\text { culture, languages }\end{array}$ \\
\hline Turkey & Ankara, Istanbul & $\begin{array}{l}\text { Balkan Communication Network, } \\
\text { TASAM World, Academy and } \\
\text { Innovation Group }\end{array}$ & History, politics \\
\hline Turkey & Edirne & $\begin{array}{c}\text { Balkan Research Institute, Republic of } \\
\text { Turkey Trakya University }\end{array}$ & $\begin{array}{l}\text { History, politics, international relations, } \\
\text { languages, literature, music cultures }\end{array}$ \\
\hline Ukraine & Kharkiv & $\begin{array}{c}\text { M. Drynov Center for Bulgarian and } \\
\text { Balkan Studies, V. N. Karazin Kharkiv } \\
\text { National University }\end{array}$ & $\begin{array}{l}\text { History, culture, Bulgarian and } \\
\text { Greek languages }\end{array}$ \\
\hline England, UK & London & $\begin{array}{l}\text { Centre for the Study of the Balkans, } \\
\text { Goldsmiths, University of London }\end{array}$ & $\begin{array}{l}\text { History, politics, anthropology, } \\
\text { sociology, theatre and performance, } \\
\text { media, cultural studies }\end{array}$ \\
\hline Scotland, UK & Glasgow & $\begin{array}{l}\text { South European Studies (Erasmus } \\
\text { Mundus Int Master) } \\
\text { (EUROSUD/EMJMD) }\end{array}$ & $\begin{array}{l}\text { Politics, international affairs, geography, } \\
\text { history, classics, law, languages, } \\
\text { economics, sociology, anthropology, } \\
\text { psychology, cultural, and media studies }\end{array}$ \\
\hline USA & $\begin{array}{l}\text { New York City, } \\
\text { New York }\end{array}$ & $\begin{array}{c}\text { Harriman Institute, Russian, Eurasian } \\
\text { and East European Studies/The East } \\
\text { Central European Center, } \\
\text { Columbia University }\end{array}$ & History, politics, culture \\
\hline USA & $\begin{array}{l}\text { Urbana-Champaign, } \\
\text { Illinois }\end{array}$ & $\begin{array}{c}\text { Balkan Studies Graduate Minor, REEEC } \\
\text { (Russian, East European, and Eurasian } \\
\text { Center), University of Illinois at } \\
\text { Urbana-Champaign }\end{array}$ & Language and area studies \\
\hline
\end{tabular}

The reluctance of these interdisciplinary institutions to offer the possibility to study Balkan music is quite surprising, given the fact that nowadays the study of music of a certain area does not necessarily require musical literacy. Namely, music can be approached from the standpoints of cultural studies, gender studies, anthropology, sociology, history, etc.--neither of which require specialized music 
expertise. In particular, there is a wide range of theoretical approaches to popular music, which has entered the academic curricula via cultural studies and related disciplines-mainly due to the fact that art music specialists had long refrained from studying the "lowly" musical genres.

Many Balkan music genres are quite well known to listeners outside of this region; as the geographical scope of contributors to this issue confirms, there is a worldwide interest in various facets of music in/from the Balkans. And yet, the global popularity of certain strands of Balkan music has not inspired the establishment of departments and study programs dedicated to the music(s) of this geographical and cultural area. Since, as we have seen, there exist many different and mutually distinguishable Balkan musics (in spite of some shared traits), it would not be very helpful to try and create a new essencialization of "Balkan Music", but rather, insist on the field being multicultural and multifaceted. Should any institution wish to begin offering specialized courses in this area, there should be a wide roster of modules available, tailored to the students' individual needs. It would be beneficial to integrate these programs into the broader fields of cultural studies, anthropology, sociology, etc., because if people in any region of the world, including the Balkans, wish to understand what is happening to them and why, they must be aware of their position in synchronic and diachronic coordinates and, even more importantly, understand in which direction(s) the rest of the world is heading. I should note that the majority of scholars who contributed to the present issue obtained their degrees from departments of musicology, ethnomusicology, music theory, composition, or dance/ballet, but without receiving comprehensive instruction on Balkan history, politics, geography, or ethnography (only Claudiu Oancea is a historian). The awareness of geopolitical trends and historical causalities would also help people in the Balkans understand why this area has not left a stronger impact on the European and global cultural scenes, and how that could be changed. The study of Balkan music and culture would teach both the peoples of the Balkans and external protagonists which traditions the cultures of the Balkans are drawing upon, which influences they received (also when and from whom), to what extent are they truly "European", etc.

On the other hand, the merits of studying music (and other arts) for people coming from other disciplines are indisputable. The study of arts and especially music enriches one's experience and helps develop transferrable skills such as originality, creativity, communication with the audience, expressing emotions, and many others. Among the specific selling points of Balkan music that could attract external students, one could list its diversity, authenticity, exoticism (both in terms of language and the oriental elements in music), its alluring joie de vivre, and many others.

When preparing curricula for the study of Balkan music, their prospective creators should also consider whether these programs should be aimed predominantly at domestic students, foreign students, or both. Aside from linguistic concerns (if aimed at attracting foreign students, courses should be offered at least partially in English), the main issue would be a disparate level of prior knowledge of the Balkans and their music among domestic students in comparison to newcomers. Namely, in many Balkan countries, especially those that have preserved the system of state-funded free specialized music and ballet schools, inherited from the socialist era (e.g., in Serbia, North Macedonia, etc.), there are programs at the primary and secondary level that enable students to learn to play traditional instruments (e.g., kaval [long woodwind instrument], gusle [single-string bowed instrument], frula [fife], gajde [bagpipes], and others), as well as traditional singing and traditional dance. The same type of instruction should be offered to foreign students wishing to learn to play these instruments, or to dance folklore dances.

In lieu of a conclusion, I hope that my fellow contributors and I have provided sufficient evidence that Balkan Music Studies is a viable and promising research field, which deserves institutional support. As is the case with any new area of study, there will be ups and downs on the road to establishing this discipline; yet, it is our hope that any stumbling blocks will be successfully overcome and that both people in the Balkans and their external counterparts will greatly benefit from studying the many musics of this long forsaken and scorned European region. 
Funding: This research was supported by the Ministry of Education, Science and Technological Development of the Republic of Serbia.

Conflicts of Interest: The author declares no conflict of interest.

\section{References}

Agawu, Kofi. 1992. Representing African Music: Postcolonial Notes, Queries, Positions. New York: Routledge. Angelov, Dimiter G. 2003. Byzantinism: The Real and the Imaginary Influence of a Medieval Civilization on the Modern Balkans. In New Approaches to Balkan Studies. Edited by Dimitris Keridis, Ellen Elias-Bursac and Nicholas Yatromanolakis. Dulles: Brassey's, pp. 3-21.

Bakić-Hayden, Milica, and Robert M. Hayden. 1992. Orientalist Variations on the Theme "Balkans": Symbolic Geography in Recent Yugoslav Cultural Politics. Slavic Review 51: 1-15. [CrossRef]

Bakić-Hayden, Milica. 1995. Nesting Orientalisms: The Case of Former Yugoslavia. Slavic Review 54: 917-31. [CrossRef]

Bohlman, Philip V. 2002. World Music: A Very Short Introduction. Oxford and New York: Oxford University Press. Boia, Lucian. 2001. History and Myth in Romanian Consciousness. Budapest: Central European University Press.

Cameron, Averil. 2006. The Byzantines. Oxford: Blackwell.

Cameron, Averil. 2014. Byzantine Matters. Princeton: Princeton University Press.

Čolović, Ivan. 2004. Balkan u naraciji o world muzici u Srbiji. New Sound 24: 59-62.

Dragićević-Šešić, Milena. 1994. Neofolk kultura: Publika i njene zvezde. Novi Sad: Izdavačka knjižarnica Zorana Stojanovića.

Dumnić, Marija. 2012. This Is the Balkans: Constructing Positive Stereotypes about the Balkans and Autobalkanism. In Musical Practices in the Balkans: Ethnomusicological Perspectives. Edited by Dejan Despić, Jelena Jovanović and Danka Lajić Mihajlović. Belgrade: Serbian Academy of Sciences and Arts -Institute of Musicology and Department of Fine Arts and Music, pp. 345-56.

Dumnić Vilotijević, Marija. 2020. The Balkans of the Balkans: The Meaning of Autobalkanism in Regional Popular Music. Arts 9: 70. [CrossRef]

Gligorijević, Jelena. 2020. Contested Racial Imaginings of the Serbian Self and the Romani Other in Serbia's Guča Trumpet Festival. Arts 9: 52. [CrossRef]

Gojkov, Stevan. 2019. Aleksandra Vrebalov, Kompozitorka: Moje teme nisu vezane za dnevnu politiku, već govore o patnji i ljudskim pobedama. MojNoviSad.com. Available online: http://www.mojnovisad.com/gradske-face/aleksandra-vrebalov-kompozitorka-moje-teme-nisu-vezane -za-dnevnu-politiku-vec-govore-o-patnji-i-ljudskim-pobedama-id28982.html (accessed on 2 September 2020).

Goldsvorti, Vesna. 2005. Izmišljanje Ruritanije. Imperijalizam mašte. Beograd: Geopoetika.

Gordy, Eric D. 1999. The Culture of Power in Serbia: Nationalism and the Destruction of Alternatives. University Park: Pennsylvania State University Press.

Iordanova, Dina. 2001. Cinema of Flames: Balkan Film, Culture and the Media. London: British Film Institute.

Jezernik, Božidar, ed. 2010. Imagining "The Turk". Newcastle upon Tyne: Cambridge Scholars Publishing.

Kronja, Ivana. 2000. Smrtonosni sjaj. Masovna psihologija i estetika turbo folka. Beograd: Tehnokratija.

Laušević, Mirjana. 2007. Balkan Fascination: Creating an Alternative Music Culture in America. Oxford and New York: Oxford University Press.

Marković, Mladen. 2002. World Contra Ethno. New Sound 24: 48-51.

Marković, Mladen. 2012. Ethno-Music in Serbia as a Product of Tradition-False or True? In Musical Practices in the Balkans: Ethnomusicological Perspectives. Edited by Dejan Despić, Jelena Jovanović and Danka Lajić Mihajlović. Belgrade: Serbian Academy of Sciences and Arts-Institute of Musicology and Department of Fine Arts and Music, pp. 333-44.

Medić, Ivana. 2014. Arhai's Balkan Folktronica: Serbian Ethno Music Reimagined for British Market. Muzikologija/Musicology 16: 105-27. [CrossRef]

Medić, Ivana. 2020. Paralelne istorije. Savremena srpska umetnička muzika u dijaspori. Beograd: Muzikološki Institut SANU.

Moody, Ivan. 2020. The Idea of Byzantium in the Construction of the Musical Cultures of the Balkans. Arts 9: 83. [CrossRef] 
Oancea, Claudiu. 2020. De-Balkanizing the Balkan: Case Studies in Romanian Ethno-Rock and Metal, and Manele. Arts. forthcoming.

Peycheva, Lozanka. 2020. Traditions in the Discussions about the obrabotvane of Folklore in the Avtorski Pesni v Naroden Duh from Bulgaria. Arts 9: 89. [CrossRef]

Samson, Jim. 2013. Music in the Balkans. Leiden: Brill.

Stokes, Martin. 2018. Notes and queries on "global music history". In Studies on a Global History of Music. A Balzan Musicology Project. Edited by Reinhard Strohm. Abingdon and New York: Routledge, pp. 3-17.

Strohm, Reinhard. 2018. Preface. In Studies on a Global History of Music. A Balzan Musicology Project. Edited by Reinhard Strohm. Abingdon and New York: Routledge, pp. xiii-xv.

Todorova, Maria. 1997. Imagining the Balkans. Oxford and New York: Oxford University Press.

Wilson, Dave. 2020. Not Different Enough: Avoiding Representation as "Balkan" and the Constrained Appeal of Macedonian Ethno Music. Arts 9: 45. [CrossRef]

Wolff, Larry. 1994. Inventing Eastern Europe. The Map of Civilization on the Mind of the Enlightenment. Stanford: Stanford University Press.

Zdravkova Djeparoska, Sonja. 2020. Macedonian Cultural Plurality at the Crossroads of the Balkans: Drama, Music and Dance. Arts 9: 85. [CrossRef]

Žižek, Slavoj. 1999. The Spectre of Balkan. Journal of the International Institute 6. Available online: https://quod.lib.u mich.edu/j/jii/4750978.0006.202/-spectre-of-balkan?rgn=main;view=fulltext (accessed on 2 September 2020).

(C) 2020 by the author. Licensee MDPI, Basel, Switzerland. This article is an open access article distributed under the terms and conditions of the Creative Commons Attribution (CC BY) license (http://creativecommons.org/licenses/by/4.0/). 